\title{
REVIEWS
}

\section{A clinicopathological classification of granulomatous disorders}

\author{
D Geraint James
}

\begin{abstract}
Granulomatous disorders comprise a large family sharing the histological denominator of granuloma formation. A granuloma is a focal compact collection of inflammatory cells, mononuclear cells predominating, usually as a result of the persistence of a non-degradable product and of active cell mediated hypersensitivity. There is a complex interplay between invading organism or prolonged antigenaemia, macrophage activity, a Th1 cell response, $B$ cell overactivity and a vast array of biological mediators. Differential diagnosis and management demand a skilful interpretation of clinical findings and pathological evidence. They are classified into infections, vasculitis, immunological aberration, leucocyte oxidase deficiency, hypersensitivity, chemicals, and neoplasia.

(Postgrad Med F 2000;76:457-465)
\end{abstract}

Professor James

Submitted 7 July 1999 Accepted 22 November 1999

Keywords: granuloma; Th1 cell; cytokines; neoplasia

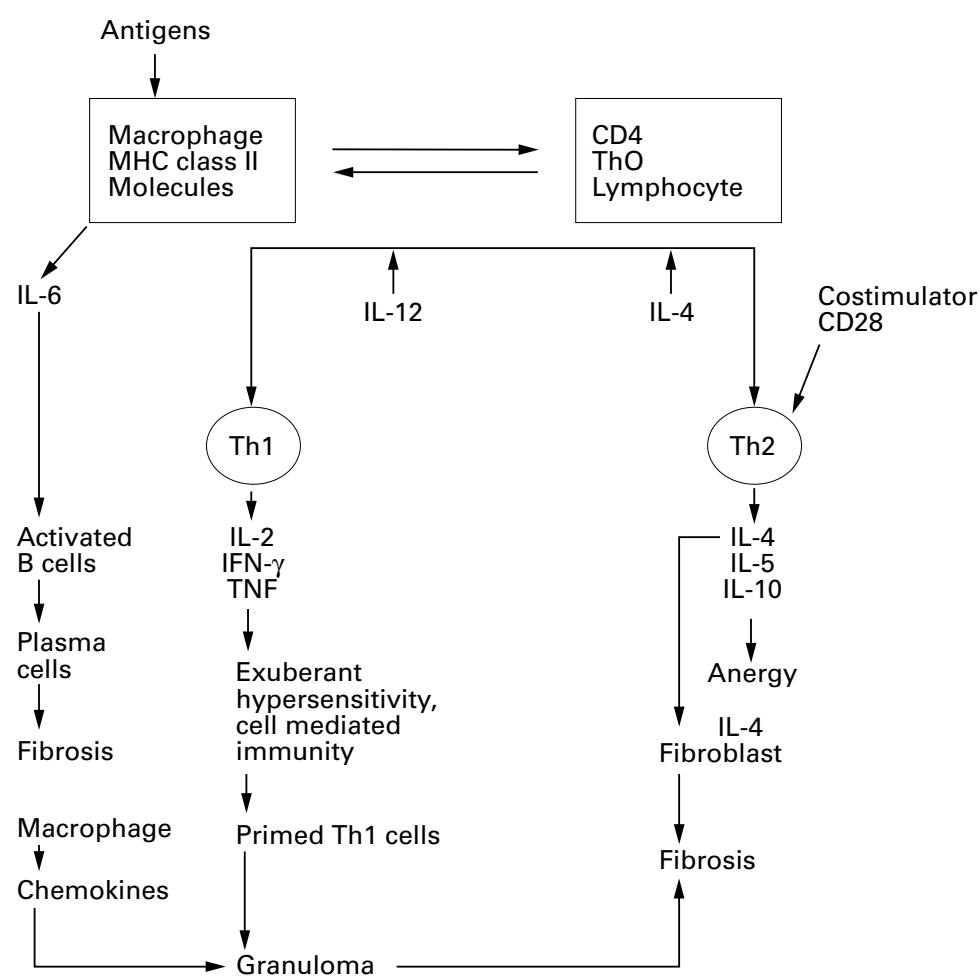

Figure 1 The cytokine network (IFN- $\gamma=$ interferon gamma; $I L=$ interleukin; $M H C=$ major histocompatibility complex; TNF = tumour necrosis factor).
Granulomatous disorders comprise a large family sharing the common histological denominator of granuloma formation. Granulomas may be confluent or discrete; the degree of necrosis is variable; the cell components differ; and the presence or absence of Schaumann bodies and of calcification are distinctive. A clinicopathological synthesis provides the most secure foundation.

\section{Granuloma formation}

A granuloma is a focal, compact collection of inflammatory cells, mononuclear cells predominating; it is usually formed as a result of the persistence of a non-degradable product of active hypersensitivity. The granuloma is the end result of a complex interplay between invading organism or antigen, chemical, drug or other irritant, prolonged antigenaemia, macrophage activity, a Th1 cell response, B cell overactivity, circulating immune complexes, and a vast array of biological mediators (fig 1). Areas of inflammation or immunological reactivity attract monocyte macrophages which may fuse to form multinucleated giant cells, and a transformation of macrophages to epithelioid cells. The granuloma is an active site of numerous enzymes and cytokines, and, with aging, fibronectin and numerous progression factors. There is a close relationship between activated macrophages bearing increased expression of major histocompatibility complex (MHC) class II molecules and CD4+ Th1 lymphocytes. These $\mathrm{T}$ helper cells recognise protein peptides presented to them by antigen presenting cells bearing MHC class II molecules. The $\mathrm{T}$ cell induces interleukin-1 on the macrophage and thereafter a cavalcade of chemotactic factors promote granulomagenesis. Interferon gamma (IFN- $\gamma$ ) increases the expression of MHC class II molecules on macrophages, and activated macrophage receptors carry an Fc fraction of IgG to potentiate their ability to phagocytose. The end result is the epithelioid granuloma which progresses under the impact of transforming - and plateletderived growth factor towards fibrosis. ${ }^{1-3}$

$\mathrm{T}$ cell activation also requires the $\mathrm{B} 7: \mathrm{CD} 28 /$ CTLA:4 costimulatory pathway. With CD28 mediated costimulator, there is active $\mathrm{T}$ cell proliferation; without it, there is ignorance, anergy, and apoptosis. ${ }^{4}$ Overstimulation of Th1 relative to Th2 cells leads to pronounced cell mediated hyperactivity, tissue destruction, and granuloma formation. This is slowed down by B7-1 or B7-2 antagonists. The opposite occurs 
Table 1 Classification of granulomatous disorders

\begin{tabular}{|c|c|c|}
\hline (1) Infections & (2) Vasculitis & (5) Hypersensitivity Pneumonitis \\
\hline Fungi & Wegener's & Farmers' lung \\
\hline Histoplasma & Necrotising sarcoidal & Bird fanciers' \\
\hline Coccidioides & Churg-Strauss & Mushroom workers' \\
\hline Blastomyces & Lymphomatoid & Suberosis (cork dust) \\
\hline Sporothrix & Polyarteritis nodosa & Bagassosis \\
\hline Aspergillus & Bronchocentric & Maple bark strippers' \\
\hline Cryptococcus & Giant cell arteritis & Paprika splitters' \\
\hline Protozoa & Systemic lupus erythematosus & Coffee bean \\
\hline Toxoplasma & & Spatlese lung \\
\hline Leishmania & (3) Immunological aberrations & \\
\hline Metazoa & Sarcoidosis & (6) Chemicals \\
\hline Toxoplasma & Crohn's disease & Beryllium \\
\hline Schistosoma & Primary biliary cirrhosis & Zirconium \\
\hline Spirochaetes & Hepatic granulomatous disease & Silica \\
\hline $\mathrm{T}$ pallidum & Langerhan's granulomatosis & Starch \\
\hline $\mathrm{T}$ carateum & Orofacial granulomatosis & Talc \\
\hline $\mathrm{T}$ pertenue & Peyronie's disease & \\
\hline Mycobacteria & Blau's syndrome & (7) Neoplasia \\
\hline M tuberculosis & Hypogammaglobulinaemia & Carcinoma \\
\hline M leprae & Histiocytosis X & Reticulosis \\
\hline M kansasii & Immune complex disease & Pinealoma \\
\hline $\mathrm{M}$ marinum & & Dysgerminoma \\
\hline$M$ avian & (4) Leucocyte oxidase defects & Seminoma \\
\hline BCG vaccine & Chronic granulomatous disease of childhood and adults & Reticulum cell sarcoma \\
\hline \multirow{2}{*}{\multicolumn{3}{|c|}{ Malignant nasal granuloma }} \\
\hline & & \\
\hline \multirow{6}{*}{ Yersinia } & & (8) Miscellaneous infections \\
\hline & & Whipple's disease \\
\hline & & Cat scratch \\
\hline & & Lymphogranuloma \\
\hline & & Kikuchi \\
\hline & & Buruli ulcer \\
\hline
\end{tabular}

when Th2 seems to override Th1 influences. There is anergy and apoptosis, which may be reversed by CD28 agonists.

Immunohistochemistry has revealed a continuing role for fibronectin, collagen, integrin receptors, and transforming growth factors in that slippery road from a healthy granulomatous response to irreversible and unchangeable fibrosis.

\section{Classification}

This large family of granulomatous disorders comprise infections, vasculitis, immunological upsets, leucocyte oxidase defect, hypersensitivity, chemicals, and neoplasia (table 1). Differential diagnosis and management demand a skilful interpretation of clinical findings and histology ${ }^{5}$ (table 2).

\section{(1) INFECTIONS}

Infections are the commonest causes of disseminated granulomatous disease (table 2). Some experts regard an infection as the root cause of all such disorders but that it still remains undetected in some; over the past decade advances in molecular diagnostic techniques have allowed identification of causal organisms that were previously unrecognised. For instance, cat scratch disease is due to Bartonella henselae and Whipple's disease due to
Tropheryma whippeli. Infective causes are suspected but not yet established for sarcoidosis, Crohn's disease, primary biliary cirrhosis, Kikuchi's disease, Langerhans' granulomatosis, and chronic granulomatous disease of childhood. The aetiology, course, prognosis, and treatment of granulomatous infections have been reviewed elsewhere. ${ }^{6}$ The present review draws attention to some which currently give rise to diagnostic confusion.

\section{Mycobacterial infections}

This large family of mycobacteria is responsible for granulomatous disorders of many different systems (table 3). The invading organism is met by a vigorous cell mediated hypersensitivity reaction involving macrophages, Th1 lymphocytes, and their cytokines. The polymerase chain reaction (PCR) has uncovered mycobacterial DNA in sarcoid tissue and mycobacterial RNA has been extracted from sarcoid spleen by liquid phase DNA/RNA hybridisation giving rise to false speculations concerning the aetiology of sarcoidosis.

\section{Swimming pool (fish tank) mycobacterial granuloma}

Mycobacterium marinum causes swimming pool (fish tank) granuloma. Although the primary

Table 2 Histological comparison of various granulomatous disorders

\begin{tabular}{|c|c|c|c|c|c|c|c|}
\hline Features & Sarcoid granuloma & Necrosis & $\begin{array}{l}\text { Schaumann } \\
\text { bodies }\end{array}$ & $\begin{array}{l}\text { Interstitial cellular } \\
\text { inflammation }\end{array}$ & Cavities & Vasculitis & $\begin{array}{l}\text { Mediastinal } \\
\text { adenopathy }\end{array}$ \\
\hline Sarcoidosis & + & - & +++ & \pm & \pm- & \pm & + \\
\hline Tuberculosis & + & ++ Caseation & \pm- & \pm & + & \pm & $+($ Primary $)$ \\
\hline Extrinsic allergic alveolitis & $+($ Acute stage $)$ & - & \pm & ++ & - & ++ & - \\
\hline Beryllium disease (chronic) & + & \pm & ++ & ++ & - & - & - \\
\hline Wegener's granulomatosis & \pm & ++ Infarction & - & ++ Giant cell & ++ & ++ & Rare \\
\hline Lymphomatoid granulomatosis & \pm & ++ & - & ++ Immature & \pm & \pm & Rare \\
\hline Bronchocentric granulomatosis & + & + & - & Eosinophil & \pm & \pm & Rare \\
\hline Necrotic sarcoidal granulomatosis & + & ++ & - & ++ Mature & + & ++ & \pm \\
\hline Churg-Strauss granulomatosis & ++ & ++ & - & ++ Mature & - & ++ & Rare \\
\hline
\end{tabular}


Table 3 Granulomatous mycobacterial infections

\begin{tabular}{lll}
\hline Clinical disorder & Common site & Mycobacteria \\
\hline Tuberculosis & Lung & M tuberculosis \\
& Meninges & \\
& Skin & \\
& Intestine & M leprae \\
Leprosy & Skin & \\
Tuberculoid & Nervous system & \\
Lepromatous & Soft tissues & M avium complex; $M$ kansasii $;$ \\
Bronchopneumonia & Lung & M xenopi; $M$ simiae; \\
Lymphadenitis & Lymph node & M scrofulaceum; $M$ chelonee; \\
Osteomyelitis & Bone & malmoense; $M$ fortuitum \\
AIDS & Joints & M marinum or $M$ balneum \\
Swimming pool and fish tank & Meninges & \\
granuloma & Skin & M ulcerans \\
Buruli ulcer & Draining lymph nodes & \\
& Skin & \\
\hline
\end{tabular}

skin infection may be inconspicuous, the draining lymph nodes are extensively involved and caseous. A similar microscopic picture, with conspicuous plasma cell infiltration, is associated with granulomas due to other opportunistic mycobacteria. Fish tank granulomas develop in persons with minor abrasions who dip their hands in tropical fish tanks. Usually a solitary granuloma, nodule, or pustule forms, which may ulcerate or suppurate; but, multiple lesions may extend along the line of lymphatic vessels.

Biopsy specimens that are cultured on Löwenstein-Jensen medium at room temperature yield pigmented mycobacterial colonies in 2-4 weeks. The response to treatment is variable and not dramatic. Antituberculous drugs, cotrimoxazole, and high doses of minocycline have been advocated.

The development and application of molecular techniques such as PCR may in the future allow more accurate diagnosis.
Beware also of sea urchin granuloma of the feet in bathers and fishermen stepping on sea urchins.

\section{Buruli ulcer}

Mycobacterium ulcerans is the cause of chronic, relatively painless, cutaneous Buruli ulcers. The disease is most prevalent in Africa and Australia. The organism causes extensive undermined ulcers on the extensor surface of the extremities. The centres of the ulcers are necrotic, and the edges are undermined; the organisms are usually found at the periphery, where granulation tissue is most extensive. While it is relatively easy to diagnose Buruli skin ulcers on the basis of clinical features and histological findings, microbiological identification of the causal mycobacteria may sometimes be quite difficult, requiring long periods of culture. Newer techniques such as gas phase chromatography are becoming useful for identification of the acid-fast bacilli in low count subcultures.

\section{Granulomatous mycoses}

Granulomatous fungal infections mimic sarcoidosis worldwide. It is important to recognise or exclude fungi localised to one system or disseminated; in particular, granulomatous fungal meningitis needs to be distinguished from sarcoidosis by all available techniques (table 4 ).

\section{Whipple's disease}

George Hoyt Whipple's single case report described a 37 year old medical missionary who presented with fever, polyarthritis, and steatorrhoea. ${ }^{7}$ It is a chronic multisystem granulomatous disorder affecting middle aged white males, presenting with fever, polyarthritis, weight loss, and diarrhoea progressing to malabsorption. There may be hepatospleno-

Table 4 Granulomatous mycoses

\begin{tabular}{|c|c|c|c|c|}
\hline Fungus & Clinical diagnosis & Immunopathology & Method of diagnosis & Treatment \\
\hline $\begin{array}{l}\text { Nocardia } \mathrm{sp} \\
\text { Actinomyces sp }\end{array}$ & Actinomycosis & $\begin{array}{l}\text { Pneumonia } \\
\text { Granuloma } \\
\text { Fibrosis }\end{array}$ & $\begin{array}{l}\text { Microscopy } \\
\text { Culture }\end{array}$ & $\begin{array}{l}\text { Penicillin } \\
\text { Minocycline }\end{array}$ \\
\hline Coccidioides immitis & Coccidioidomycosis & $\begin{array}{l}\text { Bronchopneumonia } \\
\text { Cavitation } \\
\text { Chronic granuloma }\end{array}$ & $\begin{array}{l}\text { Culture } \\
\text { CFT } \\
\text { ELISA } \\
\text { Tube precipitin }\end{array}$ & $\begin{array}{l}\text { Amphotericin B } \\
\text { Flucytosine } \\
\text { Fluconazole }\end{array}$ \\
\hline Cryptococcus neoformans & Cryptococcosis & $\begin{array}{l}\text { Pneumonia } \\
\text { Infarction } \\
\text { Abscess } \\
\text { Granuloma fibrosis }\end{array}$ & $\begin{array}{l}\text { Microscopy } \\
\text { Culture }\end{array}$ & $\begin{array}{l}\text { Fluconazole } \\
\text { Amphotericin B } \\
\text { Flucytosine }\end{array}$ \\
\hline Candida sp & $\begin{array}{l}\text { Candidiasis } \\
\text { Monoliasis }\end{array}$ & $\begin{array}{l}\text { Abscess } \\
\text { Necrosis } \\
\text { Granuloma }\end{array}$ & $\begin{array}{l}\text { Microscopy } \\
\text { Culture }\end{array}$ & $\begin{array}{l}\text { Nystatin } \\
\text { Amphotericin B }\end{array}$ \\
\hline $\begin{array}{l}\text { Sporothrix schenkii } \\
\text { Histoplasma capsulatum }\end{array}$ & $\begin{array}{l}\text { Sporotrichosis } \\
\text { Histoplasmosis }\end{array}$ & $\begin{array}{l}\text { Granuloma } \\
\text { Pneumonia } \\
\text { Cavitation } \\
\text { Granuloma }\end{array}$ & $\begin{array}{l}\text { Microscopy, culture } \\
\text { CFT } \\
\text { Microscopy } \\
\text { Radioimmunoassay } \\
\text { Culture }\end{array}$ & $\begin{array}{l}\text { Amphotericin B } \\
\text { Amphotericin B } \\
\text { Ketoconazole } \\
\text { Rifampicin }\end{array}$ \\
\hline Aspergillus fumigatus & Aspergillosis & Necrotising granuloma & $\begin{array}{l}\text { Microscopy } \\
\text { Culture } \\
\text { Precipitins }\end{array}$ & $\begin{array}{l}\text { Amphotericin B } \\
\text { Itraconazole }\end{array}$ \\
\hline Paracoccidioides brasilliense & South American blastomycosis & $\begin{array}{l}\text { Bronchopneumonia } \\
\text { Pulmonary cavities } \\
\text { Exudate } \rightarrow \text { granuloma }\end{array}$ & $\begin{array}{l}\text { Culture } \\
\text { Sputum } \\
\text { CFT }\end{array}$ & $\begin{array}{l}\text { Amphotericin B } \\
\text { Flucytosine } \\
\text { Sulfadiazine }\end{array}$ \\
\hline Blastomyces dermatitidis & Blastomycosis & $\begin{array}{l}\text { Microabscess } \\
\text { Pneumonia }\end{array}$ & Culture & $\begin{array}{l}\text { Amphotericin } \\
\text { Itraconazole }\end{array}$ \\
\hline $\begin{array}{l}\text { Phialophora sp } \\
\text { Madurella sp }\end{array}$ & $\begin{array}{l}\text { Chromoblastomycosis } \\
\text { Mycetoma }\end{array}$ & $\begin{array}{l}\text { Cutaneous granuloma } \\
\text { Subcutaneous granuloma }\end{array}$ & $\begin{array}{l}\text { Culture } \\
\text { Grains in pus }\end{array}$ & $\begin{array}{l}\text { Flucytosine } \\
\text { Ketoconazole } \\
\text { Itraconazole } \\
\text { Dapsone }\end{array}$ \\
\hline
\end{tabular}


megaly and generalised lymphadenopathy. Biopsy of lymph node, liver, or small intestine reveals foci of PAS staining foamy macrophages in all sites. The PAS positive material within these histiocytes corresponds with lysosomes containing bacilliform bodies. Electron microscopy reveals rod shaped bacilli, termed Whipple bacilli or T whippelii or Whipple associated bacterial organism. ${ }^{8}$ The nucleic acids extracted from an endoscopic biopsy specimen of the proximal small bowel of a patient with Whipple's disease has been subjected to nucleotide sequencing and amplification by the PCR. The resulting PCR product from the bacterial 16S ribosomal DNA was then the subject of a computer database search for the rRNA sequences most similar to it. It showed that Whipple bacilli were most likely to belong to the family of Gram positive bacteria of the rhodococcus, streptomyces and arthrobacter genera, and more weakly related to mycobacteria. PCR primers for $T$ whippeli now provide a helpful diagnostic technique. ${ }^{9}$

Cat scratch disease

Cat scratch disease or fever is also known as benign lymphoreticulosis or regional granulomatous lymphadenitis. It only occurs in humans, especially those who are scratched or bitten by kittens and then develop regional lymphadenitis proximal to the site of injury. Primary involvement is that of the lymph nodes, which first show lymphoid hyperplasia. Later, scattered granulomas with central areas of necrosis coalesce to form abscesses. $B$ henselae is the responsible Gram negative bacillus. It is identified by PCR hybridisation and indirect fluorescent antibody assay.

The histopathological features of cat scratch disease are not diagnostic and may be mistaken for tularaemia, lymphogranuloma venereum, syphilis, brucellosis, atypical mycobacterial infections, fungal infections, and toxoplasmosis. Warthin-Starry silver staining is used to detect $B$ henselae, which may be present in the early phase of the disease. A skin test antigen has been made from lymph node pus. It is inoculated intradermally, and the degree of induration and erythema is measured at 48 hours.

The cat scratch antigen skin test is positive in about $90 \%$ of patients who are clinically suspected of having the disease. This test will become redundant when techniques for amplifying specific nucleotide sequences with PCR come into general use. There is no well recognised response to antibiotics, and recovery usually occurs without treatment.

\section{Kikuchi's disease}

This disorder was described in 1972 by a Japanese pathologist and is characterised by lymphadenitis showing focal reticulum cell hyperplasia, nuclear debris, and phagocytosis. ${ }^{9}$ Clinically there is localised tender cervical lymphadenopathy with an upper respiratory prodrome. Most cases occur in women under the age of 30 years. Kikuchi's disease occurs world wide and has been often confused with toxoplasmosis, cat scratch disease, tuberculo- sis, infectious mononucleosis, and nonHodgkin's lymphoma. A viral aetiology is strongly suspected on the basis of clinical features, although serological and ultrastructural studies have not yet identified an infectious agent. ${ }^{10}$

\section{(2) VASCULITIS}

The family of vasculitic granulomatoses comprise Wegener's granulomatosis, necrotising sarcoidal granulomatosis, Churg-Strauss syndrome, lymphomatoid granulomatosis, polyarteritis nodosa, bronchocentric granulomatosis, giant cell arteritis, and systemic lupus erythematosus. They may occasionally be confused with sarcoidosis and hypersensitivity pneumonitis (extrinsic allergic alveolitis), so a careful clinicopathological synthesis is essential (table 5).

Granulomatous vasculitis is a small group of systemic disorders of unknown cause and obscure pathogenesis. It has long been considered that both humoral and cellular immune mechanisms are involved, and a cascade of cytokines may influence their course. The future management may indeed depend upon manipulation of this cytokine network.

\section{(3) IMMUNOLOGICAL ABERRATIONS}

The causal agent or antigenic insult remains unrecognised in many granulomatous disorders so they are clumsily lumped together as a group in which an immunological upset plays a major part. They are waiting for the cause to be found or the immune process better understood. Within this category are sarcoidosis, primary biliary cirrhosis, hepatic granulomatous disease, Langerhans' granulomatosis, orofacial granulomatosis, Peyronie's disease, Blau's syndrome, hypogammaglobulinaemia, and immune complex disease.

\section{Sarcoidosis}

Sarcoidosis is a multisystem disorder of unknown cause(s) most commonly affecting young adults, and frequently presenting with hilar lymphadenopathy, pulmonary infiltration, ocular and skin lesions. The diagnosis is established most securely when well recognised clinicoradiographic findings are supported by histological evidence of widespread epithelioid granuomas in more than one system. Multisystem sarcoidosis must be differentiated from local sarcoid tissue reactions. There is imbalance of CDT4:T8 subsets, an influx of Th1 helper cells to sites of activity, hyperactivity of B cells, and circulation of immune complexes. Markers of activity include raised levels of serum angiotensin converting enzyme and monocyte chemoattractant protein-1; abnormal calcium metabolism; a positive KveimSiltzbach skin test; intrathoracic uptake of radioactive gallium; and abnormal fluorescein angiography.

The course and prognosis correlate with the mode of onset. An acute onset usually heralds a self limited course of spontaneous resolution whereas an insidious onset may be followed by relentless progressive fibrosis. Corticosteroids relieve symptoms, suppress the formation of 


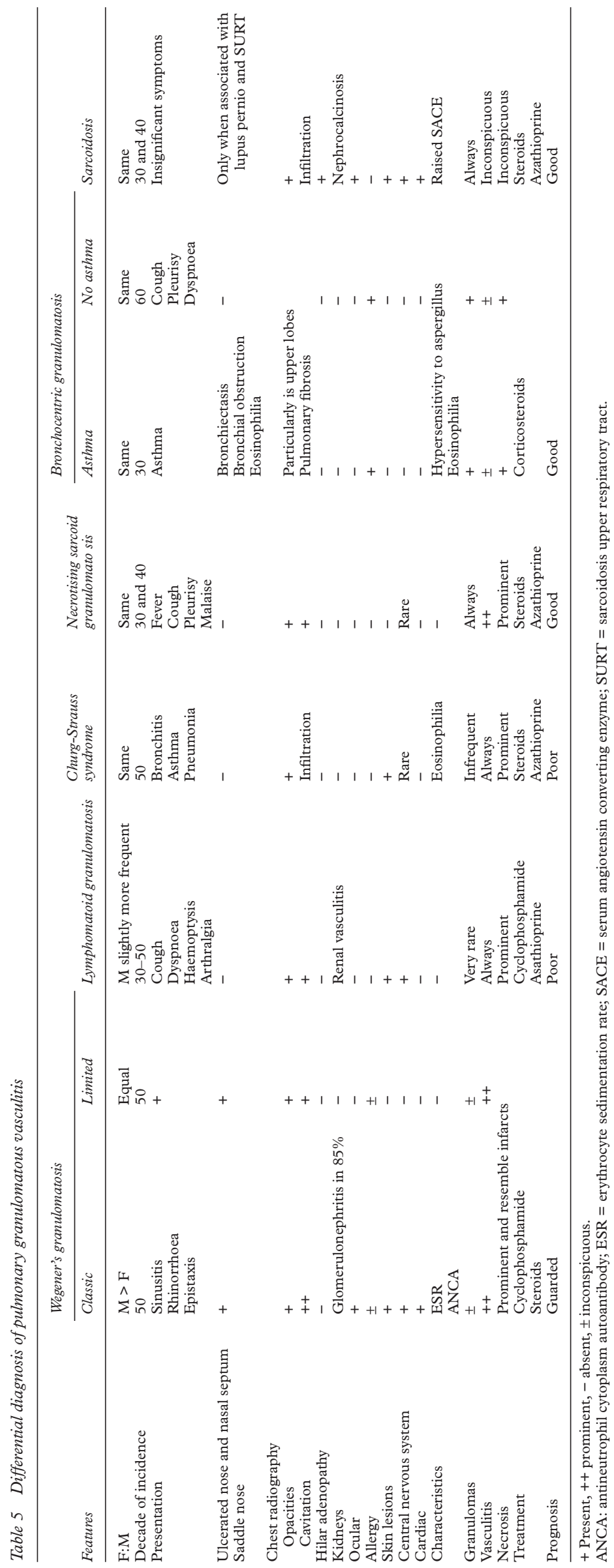

granulomas (including Kveim-Siltlzbach granulomas), and normalise both levels of serum angiotensin converting enzyme and the uptake of gallium. A synthesis of clinical features, radiology, histology, biochemical changes, and immunological abnormalities helps to distinguish it from non-specific local sarcoid tissue reactions.

Tumour necrosis factor alpha $(\mathrm{TNF}-\alpha)$ is a proinflammatory cytokine widely recognised and implicated in inflammatory disorders including sarcoidosis. It is inhibited by tumour necrosis factor receptor (TNF-R) which is recognised in two forms p55 (CD120a) and p75 (CD1206) receptors. This TNF-TNF-R balance in favour of inhibition may represent a homoeostatic mechanism which protects the patient from excessive TNF production in sarcoidosis. TNF-R p55 is increased in stage I more than stage II/III sarcoidosis, suggesting that homoeostasis is responsible for a more benign outcome at this early stage of sarcoidosis. ${ }^{11}$

\section{Crohn's disease}

The commonest cause of granulomatous inflammation in the gastrointestinal tract is Crohn's disease. This reaction seems to centre on the blood vessels of the intestinal wall causing multifocal gastrointestinal infarction. There may be associated lung changes, including pulmonary vasculitis, granulomatous interstitial lymphocytic infiltration, alveolitis, and interstitial fibrosis. Alveolar macrophages may show an increased spontaneous superoxide anion production. An increase in CD4 cells is found in bronchoalveolar fluid and even in sputum. Serum antibody increases include antireticulin antibody, antisaccharomyces cerevisiae antibody (ASCA), and p-antineutrophil cytoplasmic antibody (ANCA). There is concordance between ASCA and p-ANCA. ASCA occurs in up to $60 \%$ of patients, particularly with familial Crohn's disease; and ASCA is evident in $20 \%$ of first degree relatives. ${ }^{5}{ }^{12} 13$

Primary biliary cirrhosis (PBC)

$\mathrm{PBC}$ is a chronic non-suppurative destructive cholangitis $^{14}$ in which epithelioid granulomas are in close association with bile ducts. It predominates in women of the reproductive years of age and it is distinguished by the presence of serum mitochondrial antibodies. It is classified as an autoimmune disorder and overlaps with other autoimmune disorders including Sjogren's syndrome, rheumatoid arthritis, the calcinosis Raynaud oesophagus scleroderma telangiectasia (CREST) syndrome, scleroderma, and systemic lupus erythematosus.

Cholangiocyte apoptosis is responsible for bile duct destruction due to aberrant expression of the major autoantigen, the E2 subunit of the pyruvate dehydrogenase complex. There is some evidence that PBC with high titres of antinuclear antibodies progress slower and result in a better prognosis than those with low titre or negative antinuclear antibodies.

PBC histology may be granulomatous or alternatively eosinophilic. Could this be due to the predominant influence of either the Th1 
cytokine cascade producing granulomas or the Th2 cascade causing an eosinophilic response?

The aetiology of PBC remains unknown. There are similarities between Escherichia coli and mitochondrial components; cross reactivity between bile duct mitochondria and bacteria is a possibility. An increased incidence of Gram negative urinary tract infections is recognised in PBC. It has been likened to the chronic graft-versus-host rejection with similar structural change in the bile ducts, lacrimal and pancreatic ducts, which have a high concentration of HLA class II antigens on the epithelial surface.

A differential diagnosis of some hepatic granulomatous disorders is appended (table 6).

\section{Langerhans' cell granulomatosis}

The term Langerhans' cell granulomatosis refers to proliferative disorders of histiocytes, previously referred to as histiocytosis X. It encompasses a group of disorders of unknown aetiology characterised by granulomatous infiltration of the lungs, bone, skin, lymph nodes, and brain. ${ }^{5}{ }^{15}$ The clinical conditions have been known by several names, based on the type of presentation, sites of involvement, rate of progression, and degree of associated immune dysfunction. They include eosinophilic granuloma, Letterer-Siwe disease, and HandSchüller-Christian disease. They are different expressions of the same basic disorder, in which the proliferation of Langerhans' cells results from disturbances in immunoregulation.

Langerhans' histiocytes are bone marrow derived monocyte macrophage cells; they include Langerhans' epidermal cells, Kupffer's cells in the liver, osteoclasts, and alveolar macrophages. They are human leucocyte antigen DR positive functioning macrophages that present antigen to $\mathrm{T}$ cells and play a part in cell mediated immunity. Unlike histiocytes, Langerhans' cells can be stained immunohistochemically for S-100 protein and OKT-6.

Lung biopsy reveals a mixed cellular exudate, foam cells, eosinophils, and characteristic

Table 6 Differential diagnosis of some diseases with hepatic granulomas

\begin{tabular}{|c|c|}
\hline Disease & Diagnostic aids \\
\hline Sarcoidosis & $\begin{array}{l}\text { Chest radiograph; Kveim; SACE } \\
\text { Bronchoalveolar lavage }\end{array}$ \\
\hline Tuberculosis & $\begin{array}{l}\text { Tuberculin skin test } \\
\text { Bronchoalveolarlavage } \\
\text { Acid-fast staining } \\
\text { Isolation organism }\end{array}$ \\
\hline Brucellosis & $\begin{array}{l}\text { Blood culture } \\
\text { Agglutinin titre }\end{array}$ \\
\hline Berylliosis & $\begin{array}{l}\text { Industrial exposure } \\
\text { Chest radiograph }\end{array}$ \\
\hline Syphilis & Treponema test \\
\hline Leprosy & Race; lepromin skin test \\
\hline Histoplasmosis & $\begin{array}{l}\text { Complement fixation test } \\
\text { Chest radiograph }\end{array}$ \\
\hline $\begin{array}{l}\text { Infectious } \\
\text { mononucleosis }\end{array}$ & $\begin{array}{l}\text { Blood film, monospot, } \operatorname{IgM} \\
\text { Epstein-Barr antibodies }\end{array}$ \\
\hline AIDS & $\begin{array}{l}\text { Poorly formed granulomas } \\
\text { Acid-fast and fungal stains } \\
\text { HIV test }\end{array}$ \\
\hline $\begin{array}{l}\text { Primary biliary } \\
\text { cirrhosis }\end{array}$ & Mitochondrial antibody \\
\hline Lymphomas & $\begin{array}{l}\text { Chest radiograph; lymph node biopsy } \\
\text { Computed tomography }\end{array}$ \\
\hline
\end{tabular}

SACE $=$ serum angiotensin converting enzyme.
$\mathrm{X}$ bodies (Birbeck granules) in macrophages. Langerhans' or X bodies are an ultrastructural feature in $90 \%$ of patients. They are identical to the granules in Langerhans' epidermal cells and consist of intracytoplasmic rod, plate, or cup-like pentalaminar structures. The presence of these tennis racket shaped ultrastructural Birbeck granules is diagnostic of the disorder. They have surface adenosine triphosphate activity identifiable by gold fluorescence. These diagnostic cells are readily found by bronchoalveolar lavage, and this technique may make lung biopsy unnecessary. It may also be a likely means of detecting a possible causal agent in the future.

Orofacial granulomatosis (Melkersson-Rosenthal syndrome)

This is a rare granulomatous disorder of the mouth and adjacent tissues, involving the oral mucosa, gum, lips, tongue, pharynx, eyelids, and skin of the face.

Melkersson described an association between facial oedema and facial paralysis. ${ }^{16}$ Rosenthal added the features of lingua plicata or scrotal tongue. ${ }^{17}$ Other clinical features include granulomatous cheilitis, oedema of the gums and scalp, salivary gland dysfunction, granulomatous blepharitis, trigeminal neuralgia, Raynaud's phenomenon, and even chronic hypertrophic granulomatous vulvitis. ${ }^{18}{ }^{19} \mathrm{~Pa}-$ tients with this disorder do not have chest radiography changes, nor uveitis; and the Kveim-Siltzbach skin test is negative. This rare disorder may be immunologically mediated for the $\mathrm{T}$ cell receptor $\mathrm{B}$ (TCRVB) repertoire is restricted. ${ }^{20}$ This is evident in oral mucosal lymphocytes, and it is associated with a local $\mathrm{T}$ cell clonal expansion. These features suggest a delayed type reaction in response to an unknown antigen. Local cytokine release may be responsible for the granulomatous reaction.

\section{Blau's syndrome}

Edward Blau is a Wisconsin paediatrician who described a multisystem granulomatous disease of the skin, eyes and joints, resembling childhood sarcoidosis. ${ }^{21}$ The histology may be indistinguishable so paediatricians should be aware of significant differences between the two disorders. The most frequent manifestation is swelling of the wrists, fingers, ankles, and elbows in the first decade of life. Because of the granulomatous histology of synovial tissue, it may be misdiagnosed as tuberculosis of bone. There may be progression of flexion contractures of joints (campodactyly) due to postinflammatory fibrotic scarring at insertion points of finger and toe flexor tendons. There is a granulomatous red papular eruption of the skin with a butterfly distribution on the face. It coincides with exacerbations of the granulomatous iritis.

Blau's syndrome is a multisystem disorder in which there is no lung involvement; this may be an important difference from other granulomatous disorders.

The granulomas of Blau's syndrome are indistinguishable from those of sarcoidosis by light microscopy or by immunocytochemistry. 
However asteroid, Schaumann and conchoid bodies, organisms, calcification and crystalline inclusions, necrosis and fibrin deposition are absent.

Granulomatous hypogammaglobulinaemia On rare occasions, one wonders whether the patient has hypogammaglobulinaemia or sarcoidosis or both. Confusion arises since both conditions may present with multisystem granulomas, hypersplenism, and poor cellular immunity. The hypogammaglobulinaemia may be selective IgA deficiency or a more widespread deficiency of IgA, IgG, and IgM. There is bedside clinical evidence of loss of both $\mathrm{B}$ and $\mathrm{T}$ lymphocyte function, which is also evident by in vitro lymphoproliferative assays.

\section{(4) LEUCOCYTE OXIDASE DEFECTS}

Killing of bacteria depends on a burst of respiratory enzyme activity which leads to the production of hydrogen peroxide and superoxide in phagocytes. Neutrophils in chronic granulomatous disease of childhood (CGDC) are unable to kill some ingested bacteria because they are deficient in enzymes needed for this superoxide respiratory burst. These defective enzymes may be nicotinamide adenine dinucleotide phosphate (NADPH) oxidase, myeloperoxidase, cytochrome B, pyruvate kinase, glucose-6phosphate dehydrogenase, or the lack of lysozyme or lactoferrin, each perhaps contributing a different clinical profile. The classical X linked disorder occurs in boys aged about 5 years, presenting with hepatosplenomegaly, generalised lymphadenopathy, weeping granulomatous skin lesions, and diffuse miliary lung infiltration. The history is of multisystem sarcoid granulomas. There is more than one $\mathrm{X}$ linked form and also more than one autosomal recessive variety, for there is more than one mechanism for initiating oxidative metabolism. ${ }^{22}$ Patients with CGDC suffer from infections with catalase-producing staphylococci and enterobacteria. Organisms that lack catalase supply the neutrophil with the hydrogen peroxide for their own destruction. Thus catalase negative organisms, such as pneumococci or streptococci, present no problem to these patients. Neutrophil leucocytes of normal patients with bacterial infections reduce nitroblue tetrazolium from colourless to form blueblack formazan granules in the cytoplasm. This fails to occur in the leucocytes of CGDC children or in the mothers of the $\mathrm{X}$ linked variety. The $\mathrm{X}$ linked variety is due to mutations in the gene for the gp 120-phox subunit of the phagocyte cytochrome $b$, an essential component of superoxide-generating NADPH oxidase. Most patients have undetectable levels of cytochrome $\mathrm{b}$ and no phagocyte NADPH oxidase activity. This gives rise to life threatening bacterial and fungal infections in infancy. Some patients have a milder course because they retain some cytochrome NADPH oxidase activity.

IFN- $\gamma$ has proved helpful in enhancing host defences and thereby reducing the incidence of life threatening infections, particularly those infections characterised by persistence in macrophages (toxoplasmosis, leishmaniasis, and mycobacteriosis). ${ }^{9}$
Thrasher et al used an adenovirus vector expressing p47-phox to transduce patients' defective monocytes. ${ }^{23}$ Nitroblue tetrazolium staining indicated that NADPH oxidase activity was restored to those cells. This technique offers a rapid means for molecular diagnosis and points to a therapeutic future of gene transduction.

Chronic granulomatous disease in adults (CGD) Chronic granulomatous disease is being recognised more commonly in adults. Although it is still rare it should be excluded in adults with unexplained granulomas or infections. ${ }^{24}$ Antibiotic prophylaxis and the use of IFN $-\gamma$ has allowed children, mostly with reduced gp91phox (X91-CGD), to present for the first time in young adult life. The NBT is insufficient as a screening test for it may give values close to normal in adults. It should be complemented by chemoluminescence or cytochrome $b$ reduction. This is important because of the benefits of earlier diagnosis and treatment, infection prophylaxis, and genetic counselling.

\section{(5) HYPERSENSITIVITY PNEUMONITIS (EXTRINSIC} ALLERGIC ALVEOLITIS)

Repeated inhalation of various antigens may provoke a granulomatous inflammatory response in the bronchoalveolar spaces and interstitium giving rise to a family of pulmonary disorders termed hypersensitivity pneumonitis or extrinsic allergic alveolitis. The best recognised members of the family are farmers' lung, pigeon breeders' lung, and humidifier fever. The clinical picture may be acute and explosive, subacute and insidious, or chronic and protracted; cough and dyspnoea on exertion, fatigue, and weight loss are common. The end stage is characterised by irreversible restrictive lung function and cardiac failure. Pathogenesis involves a complex interplay of circulating immune complexes, immediate hypersensitivity, and exuberant cell mediated immunity. The diagnosis is established by a history of occupational exposure; suggestive clinical and radiological changes; and demonstration of precipitating serum antibodies. Mid to late inspiratory crackles and the absence of finger clubbing are notable features. An increase in CD8+ $\mathrm{T}$ cells in bronchoalveolar fluid is also noteworthy.

(6) CHEMicals

There are four granuloma forming chemicals: beryllium, zirconium, silica, and talc. ${ }^{513}$

Beryllium disease mainly affects the lungs following inhalation of soluble, finely particulate beryllium and its salts. Direct implantation may also give rise to skin ulcers and nodules. Pulmonary disease may be acute or chronic (CBD); the former is a chemical pneumonitis after massive exposure to fumes whereas CBD is a chronic granulomatous disorder. It is due to occupational exposure in a variety of industrial processes, alloy workers, ceramic workers, and in space and atomic engineers. The respiratory symptoms are in keeping with diffuse and nodular fibrosis of the lungs, with pleural thickening and late cystic changes. The granu- 
loma contains a variety of inclusion bodies, Schaumann and asteroid; they are end products of the actively secreting epithelioid cells. Diagnostic criteria include history of exposure; consistent clinicoradiological features, granulomatous histology, and tissue analysis for beryllium.

\section{Zirconium}

This chemical was recognised as a cause of deodorant axillary granulomas in sensitised individuals. A 1:10 000 solution of zirconium chloride or nitrate inoculated intradermally produced a palpable nodule, which, on biopsy, revealed sarcoid tissue. This was specific for zirconium hypersensitivity. This skin test is very similar to the Kveim-Siltzbach skin test for sarcoidosis. Zirconium is no longer in deodorants so these axillary granulomas are no longer seen. However it is of some academic interest that there are four granulomatous disorders in which skin tests behave in this peculiar fashion, mimicking the Kveim-Siltzbach test. The other two were the beryllium patch test and the Mitsuda skin test in lepromatous leprosy.

Silicosis

Inhalation of pure silica may be followed by dense nodular and rarely diffuse pulmonary fibrosis. The silica granuloma is readily identified by the presence of crystalline birefringent crystals in macrophages with foreign body rather than Langhans-type giant cells.

Pulmonary talc granulomatosis

This is due to the inhalation of talc in the form of talcum powder or by prolonged repeated intravenous administration of pentazocine (75\% talc).

\section{(7) NEOPLASIA}

There is often a granulomatous component in malignant disease. Sarcoid granulomas may be found in various tumours and in their draining lymph nodes, particularly those draining carcinoma of the lung, stomach, and uterus. They may also be found in tumours that have been treated by radiotherapy or chemotherapy, since treatment may produce a granulomagenic substance which spreads to draining lymph nodes.

There is diagnostic confusion between sarcoidosis and Hodgkin's disease, in which multisystem granulomas are also observed. The difficulty usually arises in the interpretation of small specimens of aspiration liver biopsies, or the occasional patient in whom the spleen is replaced by sarcoid tissue obliterating tumour tissue. Intrathoracic Hodgkin's disease most frequently affects the upper mediastinum rather than hilar lymph nodes, and it is predominantly unilateral. The hilar nodes tend to fuse with the right cardiac border whereas in sarcoidosis they stand away from the cardiac border. Both disorders show depression of cell mediated immunity. In Hodgkin's disease, the Kveim-Siltzbach test is negative and serum angiotensin converting enzyme levels are raised in only about $10 \%$ of patients, compared with $60 \%$ in sarcoidosis.
(8) MISCELLANEOUS

Granulomatous angiitis

Granulomatous angiitis is a multifocal chronic inflammatory disorder in which magnetic resonance imaging may show multiple discrete granulomas. The initial diagnosis may suggest an infection, such as tuberculosis or toxoplasmosis, or alternatively intravascular lymphomatosis.

\section{Granuloma annulare}

These skin lesions may be single, multiple, or disseminated with flat centre and a well delineated edge. The histology is of a necrobiotic area with palisading granulomas in giant cells. A similar histological reaction may be seen in rheumatoid disease and with a ruptured sebaceous cyst.

\section{Actinic granuloma}

This disfiguring condition is a granulomatous reaction to excessive sun exposure. There is debate whether it is a distinct clinicopathological entity or a variant of granuloma annulare or multiforme and necrobiosis lipoidica. Treatment with isotretinoin has prevented development of new granulomas and produced almost complete resolution of established lesions.

\section{Granulomatous rosacea}

Rosacea has been described as the curse of the Celts. ${ }^{25}$ It is commoner in women, aged 30 to 50 years. There is a background diathesis of flushing and blushing, upon which develops erythema, papules, pustules, telangiectasia, furuncles on the face, neck and v-shaped area of the chest. Granulomatous or lupoid rosacea nodules may also involve the lower eyelids. Histology reveals perifollicular and perivascular granulomas; it needs to be distinguished from micronodular sarcoidosis, particularly since both conditions may be associated with iritis and conjunctivitis. Minidose isotretinoin, $2.5 \mathrm{mg}$ to $5 \mathrm{mg}$ daily, oral tetracycline, or metronidazole may be helpful for lupoid rosacea.

Other

Do not be surprised if the histological report of a removed sebaceous cyst indicates a granuloma. The same granulomatous reaction occurs in chalazion, dermoid, panniculitis, sea urchin spine injury, tattoos, or malakoplakia. It indicates a vigorous macrophage Th1 reaction to the antigenic insult, involving cytokines and other biological mediators (fig 1). It indicates a good defence and a satisfactory outcome against the antigenic aggression.

1 James DG. What makes granulomas tick? Thorax 1991;46:734-6.

2 James DG.Granuloma formation signifies a Th1 cell profile. Sarcoidosis 1995;12:1-3

3 Roman J, Leon YJ, Gal A, et al. Distribution of extracellular matrices, matrix receptors, and transforming growth factor-1 in human and experimental living granulomatous inflammation. Am f Med Sci 1995;309:124-33.

4 Reiser H, Stadecker MJ. Costimulatory B7 molecules in the pathogenesis of infectious and autoimmune diseases. NEngl f Med 1996;335:1369-77.

5 James DG, Zumla A. The granulomatous disorders. Cambridge: Cambridge University Press, 1999.

6 Zumla A, James DG. Granulomatous infections: etiology and classification. Clin Infect Dis 1996;23:146-58.

7 Whipple GH. A hitherto undescribed disease characterised anatomically by deposits of fat and fatty acids in the intestinal and mesenteric lymphatic tissues. fohns Hopkins Hospital Bulletin 1907;18:382-91. 
8 Spapen HDM, Segers O, DeWit N. Electron microscopic detection of Whipple's bacillus in sarcoidlike periodic acidSchiff-negative granulomas. Dig Dis Sci 1989;34:640-3

9 Kikuchi M. Lymphadenitis showing focal reticulum cell hyperplasia with nuclear debris and phagocytosis. Nippon Ketsueki Gakkai Zassi 1972;35:378-80.

10 Kuo TT. Kikuchi's disease (histiocytic necrotising lymphadenitis). A clinicopathological study of 79 cases with an analysis of histologic subtypes, immunohistology, and DNA ploidy. Am F Surg Pathol 1995;7:798-809.

11 Armstrong L, Foley NM, Millar AB.Inter-relationship between tumour necrosis factor-alpha (TNF- $\alpha$ ) and soluble receptors in pulmonary sarcoidosis. Thorax 1999;54:52430.

12 Vermeire S, Peeters M, Joossens S, et al. The value of anti-saccharomyces cerevisial antibodies (ASCA) as clinical marker in Crohn's disease (CD). Gastroenterology 1999;116: marker in 3647 .

13 James DG, Jones Williams W. Sarcoidosis and other gramulomatous disorders. Philadelphia: WB Saunders, 1985.

14 Sherlock S, Dooley J. Diseases of the liver and biliary system. 10th Ed. Oxford: Blackwell, 1997: 461.

15 Hance AJ, Candranel J, Soler P, et al. Pulmonary and extrapulmonary Langerhans' cell granulomatosis (histiocytosi X). Semin Respir Med 1988;9:349-68.

16 Melkersson E. U fall au recidiverande facialispares. Hygiea 1928;90:737-41
17 Rosenthal C. Facialislahmung und lingua plicata. Z Neurol Psychol 1930;131:475-501.

18 Wiesenfeld D, Ferguson MM, Mitchell DN, et al. Oro-facial granulomatoses. A clinical and pathological analysis. $Q \mathcal{F}$ Med 1985;54:101-13.

19 Larsson E, Westmark P. Chronic hypertrophic vulvitis-a condition with similarities to cheilitis granulomatosa. (Melkersson-Rosenthal syndrome). Acta Derm Venerol (Stockh) 1978;58:92-3.

$20 \mathrm{Lim} \mathrm{SH}$, Stephens P, Cao QK, et al. Molecular analysis of T cell receptor variability in a patient with orofacial granulomatosis. Gut 1997;40:683-6.

21 Blau EB. Familial granulomatous arthritis, iritis and rash. $\mathcal{f}$ Pediatr 1985;5:689-93.

22 Curnette JT. Chronic granulomatous disease: the solving of a clinical riddle at the molecular level. Clin Immunol Immunopathol 1993;67:S2-15.

23 Thrasher AJ, Casimir CM, Kinnon C, et al. Gene transfer to primary chronic granulomatous disease monocytes. Lancet 1995;346:92-3.

24 Schapiro BL, Newburger PE, Klempner MS, et al. Chronic granulomatous disease presenting in a 69 year old man. $N$ Engl f Med 1991;325:1786-90.

25 Jansen T, Plewig G. Rosacea: classification and treatment. $\mathcal{f}$ $R$ Soc Med 1997;90:144-50. 